\title{
Financial system reform and implications
}

\author{
Michael Hasenstab
}

From 1978-98 China dramatically changed its mechanism for distributing capital within the economy from a strictly planned bureaucratic system to a hybrid of state and market allocation by dismantling the credit plan and promoting the development of new financial markets to service changes in the real sector. After creating a semi-commercial banking sector and private capital markets it became possible to begin securitising financial assets in the form of loans and securities and to increasingly do away with outright government transfers and subsidies. Although residual non-performing loans and an incomplete privatisation of the state-owned sector continue to limit the government's ability to liberalise the financial sector fully, and government intervention and market manipulation still occur, irreversible steps have been made towards a more comprehensive liberalisation in the future.

Reform of the financial sector has had several very important effects on the Chinese economy in the last twenty years. First, laying the foundations to create a real central bank, deepening government debt and money markets, and partially commercialising bank operations greatly improved the government's ability to direct monetary policy through open market operations. Second, market-driven securities markets provide essential information through real prices and capital 
to the real sector in a more efficient and profit maximising manner. Finally, government and private securities markets are essential for both the re-capitalisation and the privatisation of the state-owned sector.

\section{Transition from planned to market allocated capital}

As the credit and cash plans were dismantled, innovations in the banking, capital, and money markets quickly circumvented the remaining parts of the plan to develop a parallel-albeit slightly inefficient and small relative to the overall economy-market driven financial sector.

\section{The credit plan}

From the beginning of reform until recently, China operated under an increasingly broad credit plan-setting money supply as a function of planned growth, prices and trends in money velocity. Prior to 1978 , enterprise profits were remitted to the government and then reallocated directly to priority firms through the credit plan aimed at banks and through the cash plan aimed at currency in circulation for household, enterprise and government cash needs. ${ }^{1}$ The central and local branches of the People's Bank of China (PBC) executed this State Council plan, giving specialised and universal banks specific assets and liabilities, working capital, long-term loans, and technical renovation loan targets. The credit plan restricted specialised banks from freely lending funds and since deposits were often in excess of quota lending levels, banks were forced to hold costly excess reserves at the central bank.

Changes to the system of profit remittances, direct subsidies, and transfers to the real and banking sector were some of the first critically important modifications to the credit plan system. As firms were allowed to retain an increasingly large share of corporate earnings, financial deepening naturally resulted as firms began to increase their use of simple financial instruments (for example, holding cash outside the banking sector and taking on direct loans from banks and non-bank institutions) and decrease their reliance on government transfers. For example, by 1981 banks were allowed to retain 38 per cent of after-tax profits for lending and to pay employees' bonuses and provide welfare services. ${ }^{2}$ Figure 6.1 provides an initial overview of financial deepening in China through such common measures as the ratio of M1 to GDP and M2 to GDP. 
In addition to changes at the enterprise level, as the central banking system increasingly decentralised, the credit plan began to break down and credit was often extended in excess of the plan at the local level except during periods of strict monetary retrenchment. During the period 1986-90 the credit plan was usually exceeded by about 22 per cent according to Girardin's (1997) calculations, with the central bank ultimately filling this gap. Furthermore, although the government tried to bring new financial agents into the plan-non-bank financial institutions (NBFIs) were brought under the credit plan in 1988-unofficial and NBFI activity has been very difficult to regulate and they have tended to extend credit well in excess of planned credit limits especially during such periods as 1992-93. Finally, an increasingly dynamic inter-bank market made it nearly impossible to follow the credit plan.

Given the plan's outdated role, in 1998 the government abolished the credit quota system for state-owned banks-something already mandated for other commercial banks, cooperatives, and shareholding commercial banks-and thus moved closer to a market-driven banking system.

\section{Figure 6.1 China's financial deepening, 1978-97}

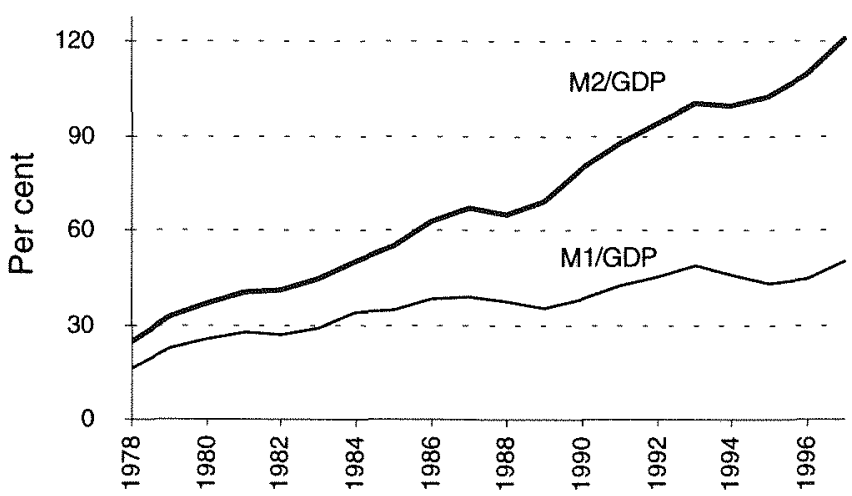

Notes: $M 1=$ money held outside bank system + demand deposits, $M 2=$ quasi money $+\mathrm{M} 1$

Source: International Monetary Fund (IMF), (various years). International Financial Statistics, IMF, Washington, DC, various issues. 


\section{Interest rates}

In the early phases of reform the central bank maintained strict control over interest rates, setting preferential rates for priority sectors, regions, and types of loans. In the late 1980s and early 1990 s the government increasingly liberalised lending rates, allowing banks to adjust rates plus or minus 10 to 35 per cent around the central bank set level. Furthermore, the development of a basic inter-bank market which eventually allowed lending between regions, and of non-bank financial institutions (NBFIs) which could offer higher deposit rates, began to circumvent the effectiveness of interest rate controls. However, the government continues to fix bank deposit rates at sub-market levels as a critical means of supporting the state-owned banking sector despite the distortions created throughout the economy.

\section{Banking and financial services}

Many researchers cite a fall in state appropriated investment in fixed assets as a measure of the declining role of the state. Such investment did fall from 16 per cent in 1985 to 3.2 per cent in 1994 (Girardin 1997). However, this does not necessarily imply a diminished role for state directed investment given that the state can still direct state bank lending. Examination of total assets in the banking sector given in Table 6.1, the emergence of multiple types of non-state bank financial institutions and the somewhat diminished role of state directed finance can better illustrate the changing role of the state. While this table illustrates some change, it also clearly shows that the least efficient state bank sector still has majority control over total assets and thus given the high levels of non-performing loans generated within this sector China continues to face the risk of a systemic bank sector crisis if reforms are not continued.

China's bank sector remains highly unprofitable and has some of the world's highest levels of non-performing loans in both absolute and relative terms, the result of heavy lending to the loss making stateowned sector, speculative investing, poor project risk evaluation, outdated accounting procedures, a lack of discounted cash flow analysis and the lack of a profit motive and an inefficient payment and settlement system forcing banks to hold excess cash for operational needs despite the high cost. Recently the People's Bank of China conservatively 


\section{Table 6.1 Breakdown of China's bank sector assets}

Institution

tate commercial banks ${ }^{1}$

Rural credit cooperatives

Other commercial banks ${ }^{2}$

Specific depositories ${ }^{3}$

Urban credit cooperatives

Foreign funded banks ${ }^{4}$

Finance companies

Total

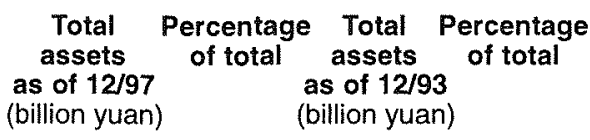

$7,213.45$
$1,040.46$
778.11
681.27
498.94
313.97
100.52
$10,626.72$

67.9
9.8
7.3
6.4
4.7
3.0
0.9
100

78.0

8.8

4.6

5.5

2.8

n.a.

0.4

100

Notes: 'State commercial banks include the Industrial and Commercial Bank of China, the Agricultural Bank of China (ABC), the Bank of China, and the People's Construction Bank of China. ${ }^{2}$ Includes the Bank of Communications, China International Trust and Investment Corporation (CITIC), Everbright Bank, Hua Xia Bank, China Investment Bank, Guangdong Development Bank, Shenzhen Development Bank, Shenzhen Merchant Bank, Pudong Development Bank, Fujian Industrial Bank, Hainan Development Bank, Minsheng Bank, Yantai Housing and Savings Bank, Bengbu Housing and Savings Bank. ${ }^{3}$ Specific depositories include Financial Trusts, Investment Companies and Policy Banks. ${ }^{4}$ Converted into yuan at year end, rate of 8.2798 yuan/US\$, data not available for 12/93.

Source: State Information Council (SIC). Website [online]. Available at <URL:http://www.chinaeco.com/emon.htm>. People's Bank of China, 1993-98. People's Bank of China Statistical Bulletin, various issues.

estimated that 20 per cent (approximately US $\$ 1$ trillion) of the country's bank loans could be considered as non-performing (Asian Wall Street Journal, 4 January 1999), however market analysts estimate such loans to be greater than 30 per cent.

\section{The Central Bank}

The most fundamental changes in China's financial sector began in 1978 with the official separation of the People's Bank of China from the Ministry of Finance, although the People's Bank of China did not stop direct lending to the Ministry of Finance until 1994. The People's Bank of China was further developed in late 1983 with the transfer of its 
commercial banking operations to the Industrial and Commercial Bank of China-now one of China's four state-owned commercial banks. The People's Bank of China has maintained its supervisory role and its role as a lender of last resort. Recently, it has begun to assert its autonomy by attempting to effect monetary policy through open market operations.

Although the credit plan was still being used, by the mid 1990s the government began experimenting with open market operations through sales and purchases of short-term treasury bills on the Shanghai Exchange. However, while household deposits and non-state sectors are increasingly sensitive to rate changes, open market operations have been challenged by several key factors: a heterogeneous and underdeveloped treasury market inhibits the execution of open market operations; bank holdings of excess reserves with the central bank give these banks the freedom to draw on assets to counter tight monetary policy; the lack of market driven operations, ongoing subsidisation and guaranteed credit to many of the state banks and state-owned enterprises makes the economy largely insensitive to rate changes; and interest rate objectives of subsidising industry and banks limits attempts at contractionary open market operations.

Despite tremendous progress since 1978, the People's Bank of China still lacks full independence. Struggles over authority between the central and local People's Bank of China branches continue, with local branches maintaining a large degree of authority over lending and personnel despite a major recentralisation effort in 1993. As Ma (1997) observes, provincial endorsement for People's Bank of China provincial heads and provincial support for office logistics (including housing, childcare, education and general staff benefits) have greatly undermined the authority of the central bank.

In 1998 the central government addressed some of these shortcomings and restructured the People's Bank of China network to create a more efficient structure with nine regional centres that report to the central People's Bank of China and all other local People's Bank of China branches reporting to these nine regional centres. This new structure, modeled after the US Federal Reserve system, aims to increase the autonomy of the central bank, however until the People's Bank of China is no longer under the direct supervision of the State Council these recent reforms will be marginalised.

Recently, to strengthen its balance sheet and assume the role of a 'true' central bank, the People's Bank of China has also dramatically 
reduced its lending to the non-financial sector from 65.9 billion yuan at the end of 1996 to 10.5 billion yuan at the end of September 1998 (People's Bank of China and State Information Council publications and officials). However, interest bearing excess reserves of state banks held at the People's Bank of China do weaken the latter's balance sheet.

\section{State-owned and policy banks}

Although several of the major state-owned banks existed in name prior to 1979 , their purposes changed dramatically during these initial years of reform from direct government distributors of capital to financial institutions issuing interest-bearing loans to their respective sectors. The Agricultural Bank of China was officially re-established in February 1979 to handle rural lending with the help of rural credit cooperatives that formed the grass roots base for this institution. The People's Construction Bank of China was first established in 1954 but not until 1979 did it begin to issue interest bearing bank loans for construction projects. In 1980 the Bank of China was placed in charge of imports and exports, foreign exchange, and international loan transactions. The bank maintained exclusive rights to handle foreign exchange until 1985 when the other specialised banks were granted these rights. At present, specialised banks are no longer restricted to their originally designated lines of business.

These state-owned banks helped to establish the ground work for China's transition to a lending-based distribution of capital, however these banks were still subject to the direction of the State Council and they never made the transition to lending on a commercial basis as lending still went to government priority, politically well connected, and high collateral projects. In an attempt to free the specialised banks of their burden of responsibility to the state-owned sector and partially due to the macroeconomic instability of 1993 , three new policy banks were established by 1994 to further separate policy and commercial lending: the State Development Bank, the Agricultural Development Bank and the Export-Import Bank. However, the balance sheets of these banks are jeopardised by their attempts to compensate low yielding investments in government public works projects with speculative investments in such areas as real estate.

Seventy per cent of state bank lending still goes to the state-owned sector, saddling these banks with non-performing loans. Xu (1998) 
reports that the central bank continues to fund the deposit-loan gaps created by such lending. ${ }^{3}$ Furthermore, these banks have developed a major asset-liability mismatch. Seventy eight per cent of the national bank sector's ${ }^{4}$ liabilities are in the form of deposits, where urban household deposits have reached a high of 57 per cent of total deposits while enterprise deposits have fallen to a low of 36 per cent. This accumulation of non-government controlled short-term urban deposits combined with government directed lending to the state sector (often long term) makes their balance sheets highly unstable. The decline of paid-in capital to the state-owned banks from 12.1 per cent in 1985 to a mere 2.2 per cent in 1996 is further evidence of their weakness (Lardy 1998).

Although the government has directed banks to reach the internationally accepted capital adequacy ratio of 8 per cent, this has only been achieved by accounting manoeuvres and little real capital has been injected. An example was the government's attempt to recapitalise the four state-owned commercial banks by issuing 270 billion yuan of 30-year special state treasury bonds with an annually paid coupon rate of 7.2 per cent. The banks list these bonds as assets on their balance sheets bringing their total capital adequacy ratios towards 8 per cent, however no new permanent capital has been created. According to Lardy (1998), by the time bad debts and subsidiary lending is accurately accounted for and the Basle standard risk weightings are applied, all four banks likely have negative capital adequacy ratios.

\section{Non-bank financial institutions and non-state commercial banks}

As a complement to changes in the state banking sector, the PBC allowed more flexible NBFIs to rapidly develop outside the rigidities of the formal banking system, to fund the development of non state-owned enterprises. The rapid growth of these institutions has also exerted competitive pressures on other parts of the financial sector, forcing the government to increasingly liberalise the state banking sector. Of all the NBFIs, trust and investment corporations (TICs) are by far the most significant in terms of assets and market influence, although the others (finance companies, financial leasing companies, securities companies and insurance companies) all play crucial roles in allocating capital to different parts of the real economy often not serviced by the state banks. 
The first international TIC, China International Trust and Investment Corporation (CITIC) was established in 1979 to promote technology transfers and joint ventures. Its role has now expanded such that CITIC lends to most sectors of the economy. In the 1980s CITIC was clearly at the forefront of China's financial market innovation although other international TICs were soon to follow. For example, in $1982 \mathrm{CITIC}$ issued China's first international corporate bonds in Tokyo for 10 billion yen, to fund the Yizheng Chemical Fibre plant. Most international TICs are funded by deposits from enterprises, different levels of government, and institutions. Most of their liabilities are in the form of deposits, while inner bank lending often constitutes the next largest part of their liabilities.

Because they do not face the regulations imposed on state banks, TICs can successfully attract enterprise and individual deposits by offering higher interest rates, participating in a wider range of business lending activities, and engaging in foreign exchange transactions. As outlined by Hong and Yan (1997), TICs act as commercial banks by treating deposits as fixed income instruments and reaping the spread earned above this deposit rate as retained profits-not as equity as in most industrial countries. Without interest controls or sector lending requirements the TICS have greater latitude than commercial banks but at the same time until recently they had an implicit guarantee of a government bail out in the event of their default with creditors. This type of unrestricted lending environment combined with moral hazard problems led trusts to over-expose their portfolios to speculative lending and investments in the equity markets.

NBFIs flourished and by the end of 1981 there were over 600 TICs. By late 1989 the total assets of TICs reached 6.3 per cent of total financial assets (Girardin 1997). NBFls actually play an even greater role, as market participants indicate that a significant amount of activity occurs between NBFIs and state banks outside the credit plan and thus outside official statistics. While trusts provided a vehicle for banks to allocate excess capital to firms with an excess demand for credit, the People's Bank of China's inability to effectively regulate this sector led them to temporarily suspend their operations after periods of 'excessive' credit expansion. The number of international TICs peaked in mid 1988 at 745 but ended the year at only 300 after the People's Bank of China enforced closures. The People's Bank of China has continued to address abuses in the TIC sector through such landmark cases as its January 
1997 takeover of the China Agribusiness Development Trust and Investment Corporation and the October 1998 takeover of Guangdong International Trust and Investment Corp (GITIC). ${ }^{5}$ As one of the largest and most trusted international TICs, GITIC's assets and liabilities of US $\$ 2.7$ billion and US $\$ 4.3$ billion, respectively, as of the end of January 1999 indicate the tenuous nature of this sector.

Other NBFIs include the over 55,000 rural credit cooperatives that operated under the guidance of the Agricultural Bank of China until 1996 when they became independent. Prior to separation rural credit cooperatives not only implemented Agricultural Bank of China lending programs, but also undertook their own deposit gathering and lending activities (to both the rural and urban sectors). Like the state banks rural credit cooperatives have significant numbers of non-performing loans accumulated from their Agricultural Bank of China directed policy lending, and their lending practices and performance are highly variable by region, but despite this they continue to be an incredibly effective vehicle for mobilising rural deposits.

Although not as numerous as rural credit cooperatives and only started in 1987, urban credit cooperatives aim to service urban individual and small business customers and have been an important vehicle for mobilising urban savings. Like the rural credit cooperatives, urban credit cooperatives are not totally independent. In 1989 urban credit cooperatives fell within the credit plan and different urban credit cooperatives were under the supervision of either the Industrial and Commercial Bank of China, Bank of China or People's Construction Bank of China.

The insurance sector began officially after the People's Insurance Company of China was set up subordinate to the People's Bank of China in 1980. However at present, regulations restricting the deposit base of insurance companies have created a seriously underfunded insurance sector and forced many insurance companies to set up securities companies illegally to supplement their low yielding assets base of financial and government bond holdings. As a result the insurance sector has become increasingly unstable in the late 1990 s and will likely undergo a shakeout similar to the restructuring of the TICs in the near future.

Non-state commercial banks. The China Investment Bank, founded in 1981, was the first major non-state bank to be created, and was designed to attract medium and long-term capital from overseas and to facilitate lending with the World Bank. The more commercially oriented 
and comprehensive non-state banks didn't begin independent operations until the Bank of Communications was restructured in 1986 and the CITIC Industrial Bank (a subsidiary of CITIC) began operations in 1987. After 1987 similar types of banks were established in the Special Economic Zones. By the end of 1997 these banks controlled assets of 788 billion yuan and had sourced funds both domestically and internationally.

\section{Foreign banks}

Foreign institutional presence in the banking sector has been very limited due to strict government regulations. Despite this, by the end of 1997 142 foreign banks had branch offices in China and an estimated 450 representative offices had been set up (PBC 1998; SIC 1998; China Daily, December 1998). Although foreign banks were first allowed to open representative offices in 1981, it was not until 1996 that foreign banks were allowed to enter the renminbi business. In 1998 eight foreign banks ${ }^{6}$ were given increasing access to local bond trading in Shanghai and several are pending approval in Shenzhen, however this trading is limited to the inter-bank market and excludes activities on either of China's stock exchanges. The government seems intent on expanding the number of banks, however even banks with access to renminbi business are still restricted from taking local deposits, thus relying mostly on deposits from joint ventures or foreign firms operating in China. This restriction on their liabilities marginalises their investment capacity. At the end of the first quarter of 1998 renminbi assets totalled a mere 916 million yuan, with loans of 591 million yuan and 566 million yuan in deposits (China Daily, 6 December 1998).

\section{Inter-bank market}

The inter-bank money market has provided a critical mechanism for borrowing and lending outside the credit plans as well as motivating deposit-seeking behaviour among banks that were previously limited in their lending and thus had no incentive to attract deposits. Due to the demand for liquidity borrowing created by a rigid credit plan, inter-bank activity boomed after its official introduction.

Formal inter-bank markets were developed in 1986 in the cities of Changzhou, Chongqing, Guangzhou, Shenyang, and Wuhan after 
experiments with an unofficial inter-bank market in the city of Wenzhou in 1983. Also in 1986 the Shanghai Money Market opened, headed by the Industrial and Commercial Bank of China which would come to dominate more than 50 per cent of inter-bank market activities by 1998 . The market is facilitated by local financial institutions and sponsored by local branches of the People's Bank of China. It includes banks, NBFls, and as of 1998, insurance companies. The dramatic increase in interbank lending over the years following the market's inception-to 200 billion and 524 billion yuan in 1987 and 1988 respectively-indicated the demand for more liquid money markets outside the state plan. ${ }^{7}$ By 1987 over 360 money market centres had been developed across the country.

These markets were also motivated by the central government's transfer of its responsibility to finance firm's working capital to the banks despite the continuance of the credit quota system based on forecasted deposit levels. Specifically in October 1984, the People's Bank of China issued the 'Rules for the Management of Credit Funds' (linking lending to deposit levels, limiting direct overdrafts by the central bank, encouraging inter-bank lending and replacing direct transfers from the central bank with repayable credit). Additionally, motivating these markets were changes in the balance sheets of the national banking system (discussed earlier) creating a need for better access to liquid funds given the government's inability to guarantee the liabilities side of the balance sheet via administrative measures.

From the late 1980s though the mid 1990s, the inter-bank market remained poorly regulated and decentralised due to inefficient trading, settlement, and payment systems linking the different regional markets which operated at different times with different institutions dominating different markets. ${ }^{8}$ The following characteristics were the result: interest rates differed significantly between regions; poor regulation led to a focus on loan creation not liquidity; local banks were forced by local governments to borrow excessively in the market to fund local SOEs; poor regulation and central bank support created moral hazard problems that directed inter-bank borrowing into speculative fixed asset investments; and a lack of banks operating under strict profit maximising functions limited the market's sensitivity to interest rate changes.

In 1989, in an attempt to regain control of this unauthorised lending, the government set up six regional inter-bank over-the-counter trading centres in Shanghai, Wuhan, Beijing/Tianjin, Shenyang, Xi'an, and 
Chongqing. Additionally, the government stipulated that borrowing on the inter-bank market must not be used to finance fixed asset investments, as the market was designed to help banks meet shortterm liquidity shortages and that banks were not permitted to borrow in excess of 5 per cent of the previous month's deposits. The PBC also set interest rate ceilings-at a premium to People's Bank of China daily lending rates to specialised banks. ${ }^{9}$

However this failed to stop unauthorised lending, and during the early 1990 s banks would borrow from the inter-bank market to source lending to NBFls that speculated on real estate. This speculation lead to a massive accumulation of non-performing loans that fed back into the inter-bank market and the central bank was forced to inject significant liquidity into the inter-bank market to prevent its collapse. Given that financial institutions currently in default or close to default-such as GITIC, GZITIC and Guangdong Development Enterprises (GDE), among others-have significant inter-bank liabilities, further defaults in the interbank market could be a trigger for a systemic bank sector crisis given that this market still appears underfunded. In fact, when netting out inter-bank activity for the balance sheets of the state commercial banks, the people's banks, other commercial banks and the postal savings network, there is a net liability of 198 billion yuan as of September 1998-a major reversal from net lending in the early to mid 1990 s. $^{10}$ Even when factoring in other parts of the financial sector, additional credit has been created within the inter-bank market. ${ }^{11}$ This could be explained by unofficial borrowing in this market or as a result of the massive non-performing loans accumulated during the real estate crash which was subsequently recapitalised by 200 billion yuan in People's Bank of China financing.

In April 1996 the People's Bank of China again attempted to reorganise the market, centralising it in Shanghai with links to 35 other inter-bank lending centres around the country and with the involvement of 17 banks. Whereas before, technical limitations and decentralised settlement and trading practices created a very inefficient market, now one rate (CHIBOR) is widely quoted for all inter-bank activity.

Despite changes, this market continues to remain relatively insensitive to interest rate changes and continues to provide the real sector with an important source of funding for fixed asset investment. As a result, recent inter-bank trading reflects the recent slowdown in nongovernment fixed asset investment as seen in Figure 6.2. The inverted 
yield curve for 1997 and 1998 inter-bank rates despite adequate liquidity also suggests market inefficiency and indicates the lack of arbitrage opportunities. $^{12}$

\section{Government debt and foreign exchange markets}

\section{Debt issuance and fiscal policy}

Paying down the last of its domestic and foreign debts in 1974 and 1965 respectively, the central government first incurred new domestic and foreign debts in 1981 and 1978 respectively. With the central government cutting its traditional financing links to firms by phasing out full profit remittances in the beginning periods of reform while at the

\section{Figure 6.2 China's inter-bank money market trading volume}

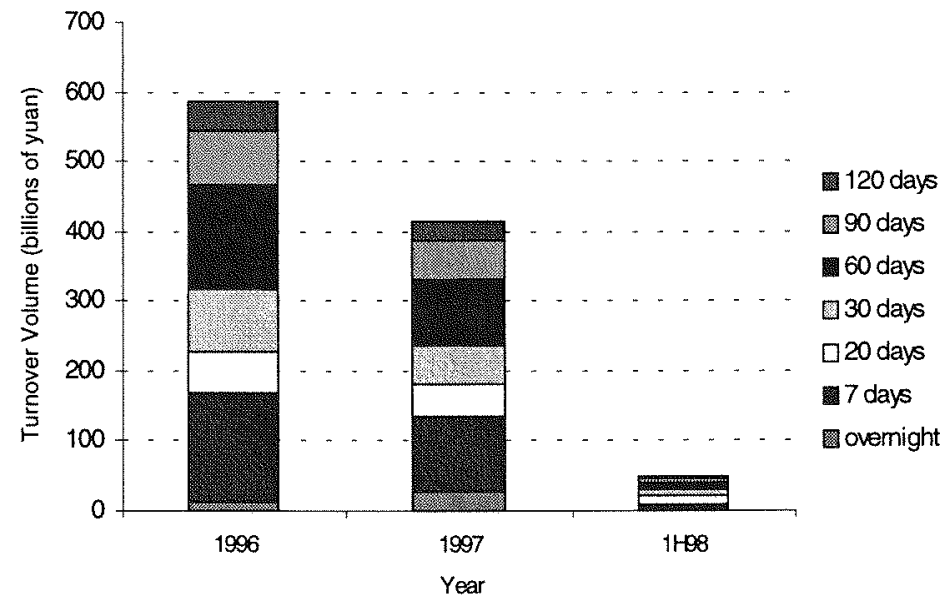

Sources: People's Bank of China, 1993-98. People's Bank of China Quarterly Statistical Bulletin, Beijing, various issues; State Information Council. Web site [online]. Available at <URL:http://www.chinaeco.com/ emon.htm>. 
same time having significant expenditure demands, the government has consistently maintained budget deficits since 1979 with the exception of 1985. These recurring budget deficits forced the government to develop their domestic and international bond issuance markets as an alternative source of finance. Figure 6.3 gives China's issuance and fiscal deficits trends to illustrate this point.

From the late 1970s to the mid 1980s both deficit and debt issuance values tended to move somewhat in tandem, with increased deficits forcing increased debt issuance (Figure 6.3). However, in the mid 1980s the government followed a steady trend of increased debt issuance while the government deficit, although deteriorating somewhat, remained relatively stable. This can best be explained by the fact that the official fiscal deficit does not capture the true extent of government spending. In fact, the government has large off balance sheet financing needs in the state-owned sector and banking sector that required large 'one-off' debt financing, and these costs do not appear as spending in the government budget. Additionally, the World Bank argues that if China were to calculate

\section{Figure 6.3 China's fiscal deficit and debt issuance profile,} 1978-98

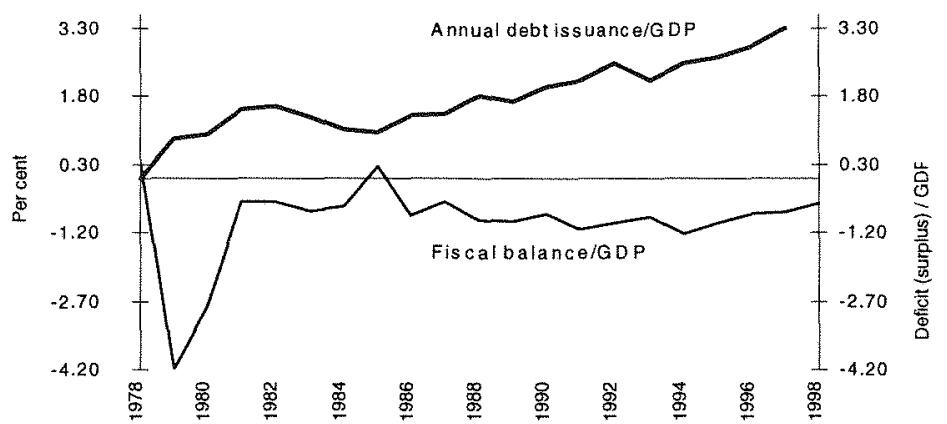

Sources: State Statistical Bureau, 1988-98. Statistical Yearbook of China, China Statistical Publishing House, Beijing, various issues; International Monetary Fund (IMF), (various years). International Financial Statistics, IMF, Washington, DC, various issues. 
its government deficit on a consolidated basis to included People's Bank of China lending to the financial system, it would approach 5 to 6 per cent of GDP. ${ }^{13}$ Furthermore, China's budget reporting lists proceeds from debt issuance as revenue. In the future, the massive debt recapitalisation needs of SOEs and the state bank sector will likely force this debt issuance as a percentage of GDP even higher. If formally incorporated in the budget, the fiscal deficit will likely exceed 5 per cent of GDP.

\section{Domestic bonds}

Placement. Since entering back into the debt markets the Ministry of Finance has issued multiple classes of bonds (treasury, fiscal, state construction, key constitution, special state, and inflation indexed) and has restricted the sale of these bonds to different holders (banks, enterprises, or individuals). The State Planning Commission also issues capital construction bonds and the various key ministries issue enterprise bonds. Bond sales in the early 1980 s were forced onto investors as pay in-kind for wages and while this type of forced placement with workers no longer occurs the Ministry of Finance continues to force enterprises and state banks to buy fiscal bonds (late 1980s and early 1990s) and various other kinds of special state bonds (ongoing).

By offering investors $100-200$ basis points above comparable bank deposit rates, the Ministry of Finance has been successful in placing the majority of new issues with retail investors and has thus become highly dependent on this class of investors and bank deposit rate controls. In 1997 China issued 241.2 billion yuan in T bonds, with 68 per cent in the form of certificate bonds and 16 per cent in unregistered bonds, both bought mostly by retail investors facing low deposit rates in the bank sector, a trend that continued into 1998.

The lack of a standardised debt market will likely hamper future issuance plans. Although yearly debt finance targets are currently given, no schedule of auction dates or sizes are provided. The government still relies on multiple classes of bonds issued by various government agencies, such as the 1.6 billion yuan 5-year Ministry of Railway bonds issued in late 1998. The lack of a smooth and liquid government yield curve from one to ten years greatly increases investor uncertainty, speculative behavior, secondary market volatility, and ultimately funding costs for the government. Additionally, while a distribution system for treasury bond auctions aimed at retail investors has been established 
via state bank branches, the government still relies on an ad hoc forced placement system for other investor classes, relying especially on the state banks to finance government spending. For example, in 1998 the central government placed 415 billion yuan in three separate bonds with state-owned commercial banks. ${ }^{14}$

Pricing. In addition to forced placement, bonds issued in the 1980 s were not market priced. For example the 10 year bonds issued in the early 1980 s paid an annual interest rate of 4 per cent payable at maturity despite 5 year bank certificate deposit rates of 6.8 per cent. After accounting for the time value of money and inflation, investors clearly lost money over this period and these bonds merely acted as a tax.

Bond issuance through the 1980 s became very unpopular and to ensure the successful placement of bond targets, the government was first forced to shorten maturities while keeping coupon rates constant. Realising that current yields were well out of line with market pricing, the government increased household bond rates from 10 per cent to 14 per cent in 1989, and for the first time it issued construction bonds with floating rates. To issue this increasing volume of bonds successfully, by 1991 the Ministry of Finance was finally forced to use a public bidding to issue bonds at market determined rates. This has most recently extended to state affiliated issuers, where for the first time the State Development Bank and Export-Import Bank issued 5 and 3 billion yuan in bonds respectively through public bidding in the second half of $1998 .{ }^{15}$

Pricing of bonds in the secondary market also still follows outdated pricing mechanisms by using a variation of current yield versus standard yield to maturity calculations. This latter pricing mechanism fails to account for the time value of money and often underprices bonds in the primary market (World Bank 1995a).

Trading. After years of illegal black market trading in treasuries, the government officially sanctioned secondary trading in July 1988 . Seven cities (Chongqing, Guangzhou, Harbin, Shanghai, Shenyang, Shenzhen and Wuhan) were established as trading centres, and securities companies and trusts began actively trading in the secondary market. However, a large supply of mispriced bonds already held by investors led to rapid selling pressure in the secondary markets in 1988 and the government was forced to use 1 billion yuan to prop up this market as individuals rushed to sell their bonds. In 1989 local governments were again forced to intervene in the secondary market - this time without central government financial support. 
In 1990 the government coordinated a national satellite linked trading system to help unify pricing across regions and allowed futures contracts on bonds to help further advance the sophistication of this market. The 1993 introduction of repurchase (repo) trading further helped institutions manage risks and allowed market makers to hold larger inventories to promote better liquidity. By 1998 almost all secondary bond market trading was done on either the Shanghai or Shenzhen exchanges through the Securities Trading Automated Quotation System (STAQS) which involves 40 domestic securities and investment and trust companies and connects with over 70 cities (Figure 6.4).

\section{Foreign bonds}

While the government first returned to the debt markets via international issuance, the Ministry of Finance has increasingly taken a conservative approach towards foreign issuance. The changed bias towards domestic versus external issuance is best illustrated in Figure 6.5.

As a result of this conservative approach China only had US $\$ 131$ billion in outstanding external State Administration of Foreign Exchange (SAFE) registered debt at the end of 1997, with a total debt service as a percentage of exports of goods, services and income of less than 10 per cent. By 1997, China had positioned its external debt portfolio inside a very safe range with US $\$ 45.3$ billion in foreign direct investment for 1997 , US $\$ 139.9$ billion in foreign exchange reserves, a current account balance of US $\$ 29.7$ billion, and a well managed maturity schedule and currency breakdown. ${ }^{16}$ Figure 6.6 shows the stability of total external central government debt to GNP over time.

However, in addition to central government debt, numerous localities and domestic institutions have been accruing significant foreign liabilities and in the past few years numerous global high yield bonds have been issued by offshore companies written on Chinese project cash flows. Guarantees for many of these bonds are often unclear despite frequent claims during investor presentations by company officials of 'government support', and potential creditor disputes could create future disruptions to China's entrance into global capital markets.

China has recently begun to aggressively develop a global sovereign yield curve, ${ }^{17}$ although there have been indications of Chinese government intervention marginalising its yields usefulness for international investors to price true China sovereign risk. ${ }^{18}$ Figure 6.7 


\section{Figure 6.4 China's treasury bond trading}

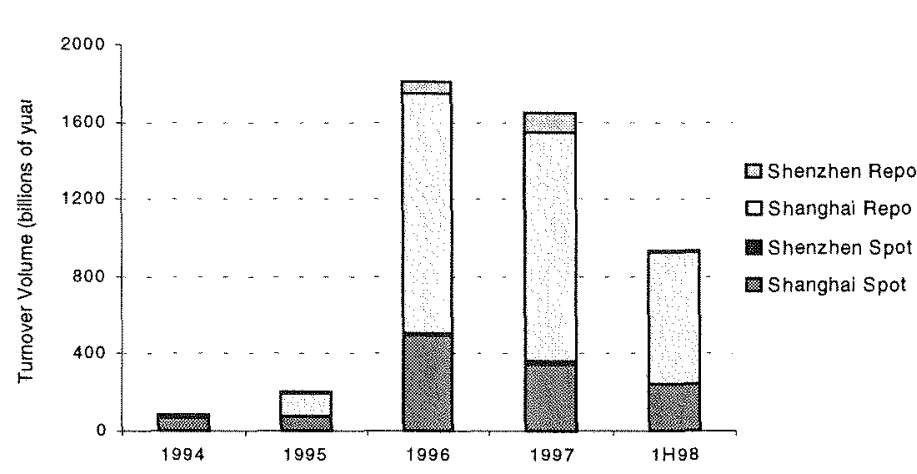

Sources: People's Bank of China, 1993-98. People's Bank of China Quarterly Statistical Bulletin, Beijing, various issues; State Information Council. Web site [online]. Available at <URL:http:/www.chinaeco.com/ emon.htm>.

Figure 6.5 China's annual domestic-external debt issuance mix, 1979-96

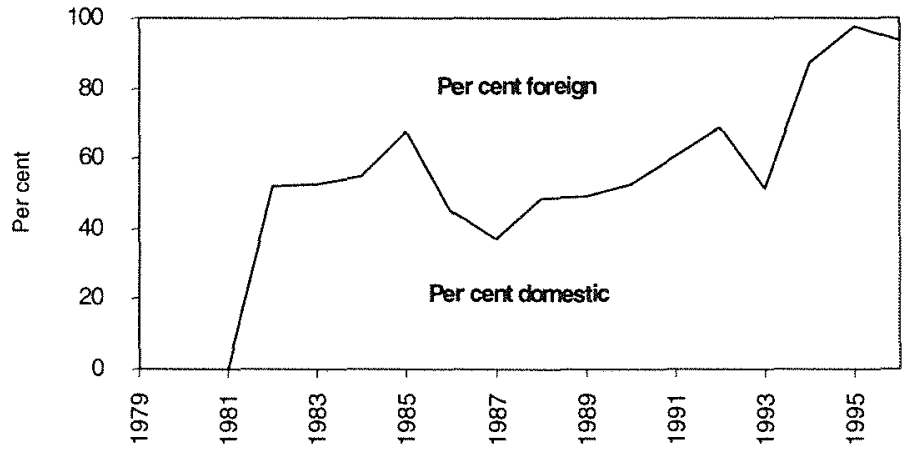

Source: State Statistical Bureau, 1988-98. Statistical Yearbook of China, China Statistical Publishing House, Beijing, various issues. 
lists the major Chinese global bonds and their sensitivity to the East Asian crisis indicates some degree of real market pricing and liquidity. All bonds listed are non-call life global bonds for the People's Republic of China with the standard government repayment guarantees rated BBB- by Standard and Poor's, except the bond maturing on 2 January 2007 which is for the SDB and is considered a quasi-sovereign.

Foreign exchange. From 1980 to late 1993 China operated two separate foreign exchange markets, the Foreign Exchange Certificate (FEC) and the renminbi (local currency) markets. The FEC market was to service the currency needs of foreign companies and persons within China and it traded at a significantly higher value in US dollar terms than the renminbi market. Initially the government could effectively ensure the separation of these two markets, but as foreign participation in the Chinese economy grew significantly, grey markets developed extensively throughout China for the trading between FEC and renminbi and for direct trading of renminbi with foreign counter parties.

The FEC was eliminated at the beginning of 1994 and existing FEC holders were forced to exchange their currency into renminbi. The exchange rate moved from 5.81 to 8.69 yuan per US dollar for foreign holders. Although the renminbi market remains very controlled, foreign exchange daily trading turnover for 1994 reached US $\$ 200$ million and involved 210 members, and currency swap centres (both informal and formal) have developed throughout the country. Officially, China has restricted currency transactions to the current account and the central bank has maintained a fixed and stable exchange rate under its closed capital account. This regime has provided stability, but it will stagnate China's attempts to develop off-shore bank markets and drive currency transactions into grey markets.

Illegal renminbi-Hong Kong dollar markets developed extensively in Shenzhen, although many of these were closed in 1998 as the government sought to enforce its strict currency regulations, limiting transaction to the trade sector only in an attempt to stabilise the yuan. Shanghai black market rates between the yuan and US dollar are also actively quoted and they have tended to put the yuan about 3 to 5 per cent lower than official rates (although they were as high as 9 per cent during periods of speculative pressure in 1998). The People's Bank of China has been seen trying to affect demand for US dollars by lowering US dollar deposit rates during 1998 in an attempt to stabilise the foreign exchange markets, however China's flat growth in reserves for the year 


\section{Figure 6.6 China: foreign debt expansion profile, 1981-97}

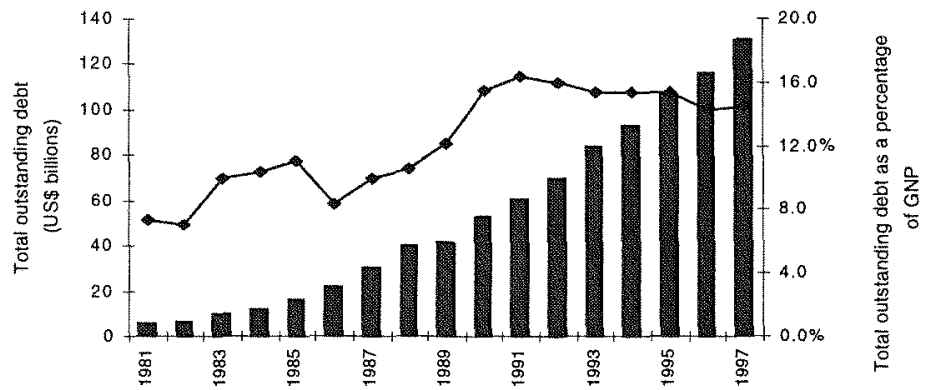

Total Outstanding Foreign Debt - Total Outstanding Foreign Debt / GNP

Source: State Administration of Foreign Exchange (SAFE), 1997. Annual Report.

Figure 6.7 China: sovereign bond performance, 8/97-10/98

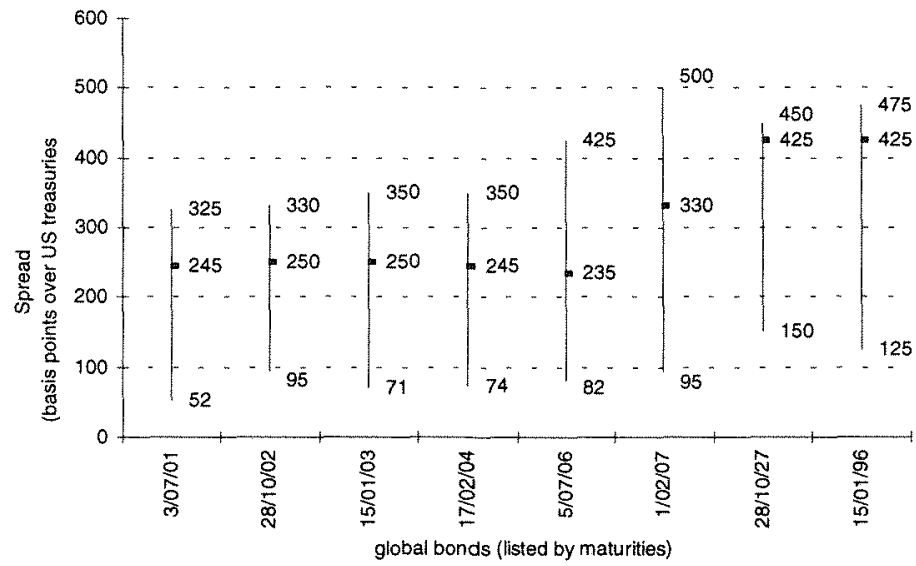

upper value is period wide lower value is period tight walue as of 10/30/98

Source: Merrill Lynch, 1998. Asian Strategy Monthly, Merrill Lynch and Company, various issues. 
despite its significant trade surplus of US $\$ 45$ billion indicates capital flight. Prior to this recent outflow, the central bank's accumulation of foreign exchange reserves from 0.16 billion yuan in 1978 to 139.89 billion in 1997 has dramatically effected domestic money growth. Although the PBC has recently allowed firms to retain increasing amounts of foreign exchange receipts and as a result has injected less renminbi into the system, the effect on the money supply remains significant.

When China moves towards opening its capital account, the current exchange rate regime will likely change significantly. Several possibilities exist, however pegging the currency against a basket of foreign currency (namely the US dollar, yen and euro) would best complement China's recent realignment of foreign exchange holdings. Another option would be to move toward a full floating exchange rate, however this idea has little support among central Chinese policymakers. With ongoing uncertainty in the Asian currency and capital markets an engineered devaluation for the sake of supporting the export sector appears very unlikely given the limited effect such a move would have on net export growth and the associated cost it would impose on China's infant capital markets.

\section{Corporate securities markets: equities and bonds}

China's tradable corporate securities markets developed on an informal basis in the mid 1980s and formally in the early 1990s. Of these markets, the equity markets have clearly been the main focal point and the most actively utilised for corporate finance and investment, leaving the corporate bond market comparatively undeveloped.

\section{Equities}

Primary issuance. Prior to the opening of the Shanghai and Shenzhen Stock Exchanges on December 1990 and April 1991 respectively, China began to issue non-tradable ownership shares as early as 1984 when it issued non-tradable employee shares for a Beijing state-owned department store. Over the next five years other SOEs issued shares after being incorporated, and joint stock companies began to emerge. 
By the end of 1998 the total market capitalisation of over two trillion yuan for the 851 listed companies on the Shanghai and Shenzhen exchanges signified the importance of these markets as a source of capital. ${ }^{19}$

Once the exchanges were opened, domestic investors were restricted to the A share markets where multiple classes of shares are issued. 'Tradable A shares', which make up a minimum of 25 per cent of total shares at the time of the initial public offering but rarely make up a controlling stake, are the only class of shares that can be traded. The government often holds a controlling interest in listed firms through its direct ownership of non-tradable state shares, while the remaining shares are distributed between other non-tradable legal person sharesowned by domestic institutions-and employee shares. To tap foreign investment sources under a closed capital account regime, China also developed a $\mathrm{B}$ share market exclusively for foreigners. Foreigners can also invest in Chinese firms through $\mathrm{H}$ shares listed in Hong Kong, $\mathrm{N}$ shares listed on the New York Stock Exchange and Red Chip stocks listed in Hong Kong (these are Hong Kong firms with most of their cash flows derived from mainland Chinese operations and are essentially considered Chinese stocks by the market). ${ }^{20}$

The central government continues to set annual stock issuance and provincial quotas, and these quotas are often under pressure from banks and other government bodies who depend on public deposits and public debt issuance and are thus afraid of potential crowding out. In addition to several objective requirements necessary for a firm to issue stocks, many domestic market participants attach a great deal of importance to political decision-making in the selection process. ${ }^{21}$ Access to initial public offerings also remains very restricted and has been a large factor in corruption scandals over the last few years.

Trading. All secondary market activity was pushed into the black market until the official exchanges were opened and even today cities such as Shenyang and Chengdu have informal stockmarkets. Cumulative trading volumes illustrate the level of activity in these markets and show their relatively high liquidity. Cumulative trading volume in $A$ and $B$ shares for the Shanghai and Shenzhen stock exchanges over the last 12 months ending 14 December 1998 reached US $\$ 301.5$ billion (Figure 6.8).

The B share market is clearly of tertiary importance and Shanghai dominates Shenzhen; weekly trading volume for 1998 was 39 per cent higher in Shanghai. 
In many aspects China's stockmarkets are remarkably well developed given their recent emergence. Trade settlements in the A share markets of one day $(T+1)$ with a limited guarantee fund set up by trading members have helped prevent wide scale systemic shocks to this market thus far. ${ }^{22}$ However, the settlement system effected by limited liability private sector corporations needs to be reformed as these corporations lack guaranteed funds in the case of wide scale defaults. Additionally, a simultaneous payment system (as opposed to an end of the day payment delivery system) would further limit default risk on both an individual and potentially systemic scale.

However, these markets have often been described by financial market observers as chaotic and speculative in their price movements. Figure 6.9 illustrates total returns in the respective markets. Some observers claim this is due to the speculative and untrained nature of local retail investors, however market manipulation, incomplete disclosure of financial statements, the regulatory structure of these markets, and government interference appear to be more significant causes of this behaviour. Moral hazard problems due to numerous government capital injections to troubled state firms listed on both exchanges have further distorted market trading behaviour.

Regulation of these markets has been incredibly difficult since their inception and massive price spikes with frequent cases of insider trading have characterised much of the domestic market's trading activity. Incorrect pricing of initial public offerings and suspect distribution have often resulted in price movements of over 100 per cent within the first two weeks of trading after issue. While the World Bank (1995a) found that A shares tended to be systematically underpriced, since 1994 empirical observations of the post initial public offering trading indicates that both under and overpricing does occur. Additionally, while Chinese authorities have prevented equity short selling in an attempt to stabilise the market, the lack of an equity repo market greatly limits the abilities of domestic institutions to manage portfolio risk and hinders the development of risk managed underwriting activities. Over the years the government has also imposed ad hoc restrictions on new share listings and daily price volatility bands-occasionally limiting daily prices changes to between 5 and 10 per cent of their opening value.

If properly enforced by the Securities Regulatory Commission, December 1998's landmark securities law-Article 214-to take effect from 1 July 1999, provides the first standardised country-wide 
Figure 6.8 Total weekly trading volume for Shanghai and Shenzhen exchanges

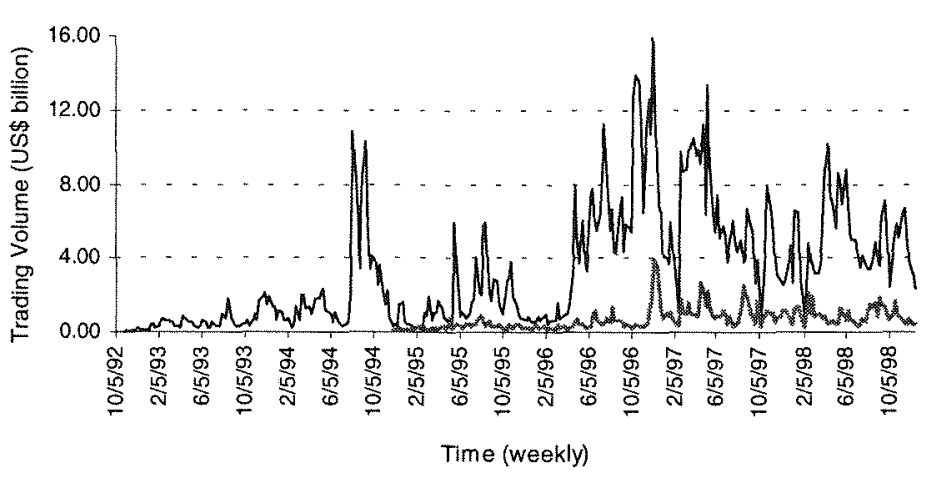

A Shares $\ldots$ B Shares

Source: DataStream.

regulations to help correct these problems by imposing stricter financial reporting guidelines, insider trading regulations, the separation of underwriting and trading activities, and the separation of client and proprietary accounts.

Bonds. Despite China's rapid development of equity markets in recent years, corporate bond markets have remained in their infant stages and have thus played only a minor role in corporate finance. Although China first started issuing corporate bonds in 1986, excessive administrative controls over issuance and ad hoc secondary trading mechanisms have burdened this market's development. At the end of 1997 the total volume of corporate bonds was 100 billion yuan with only seven corporate bonds listed on the market. Additionally, many corporate bonds are issued by the state banks or state-owned enterprises and placed in the accounts of a few state banks or other major financial institutions and little secondary trading ever occurs. Many of these bonds are simply a continuation of triangle-debt and represent refinancing loans from state banks to SOEs, and non-state firms have been a relatively small part of this market. Trading that does occur mostly 
takes place directly between two interested parties in the over-thecounter market as the major investment houses don't regularly make markets for such securities. Market participants have indicated that the approval process for corporate bond issuance is even more subjective and politicised than equity issuance and only politically well-connected companies can receive approval.

Like the equity issuance market, the government has also set an annual quota for the bond market, however the quota of a mere 20 billion yuan per year guarantees this market will remain underdeveloped. Additionally, different forms of corporate bonds are also limited, with non-straight debt such as convertible bonds making up a very small part of the overall debt market.

The lack of a liquid government yield curve also inhibits the development of a corporate bond market. Since corporate bond risk is priced in terms of bond spreads over comparable duration government bonds, then without a reliable government yield curve investors have great difficulty systemically and uniformly pricing new corporate debt. This only increases uncertainty and thus increases the cost of funding for firms forced to pay higher yields. Furthermore, China will need to establish a nationwide trading and settlement system and an active corporate bond repo market to allow underwriters to hedge their exposure when holding an inventory of their underwritten bond. ${ }^{23}$

\section{Conclusion and future policy direction}

Decentralisation and insufficient regulation have fostered overlending, brought non-performing loans to critical levels, and resulted in numerous and growing cases of institutional insolvency. However, if in the short term the People's Bank of China can successfully close, liquidate, and recapitalise the necessary institutions-primarily located in Guangdong Province-and in the long term continue to press hard for better supervision and upgrade financial reporting requirements, the benefits of allowing a vibrant private capital market to develop will greatly outweigh the costs of these problem institutions. Additionally, by actively promoting the development of the non-state banking institutions and forcing direct competition, the non-state sector will increasingly dwarf the size and influence of the less efficient state banking system.

China's future economic stability will rest largely on the ability of the $\mathrm{PBC}$ and Ministry of Finance to continue their proactive reforms and 


\section{Figure 6.9 Chinese share market returns, 1/93-12/98}

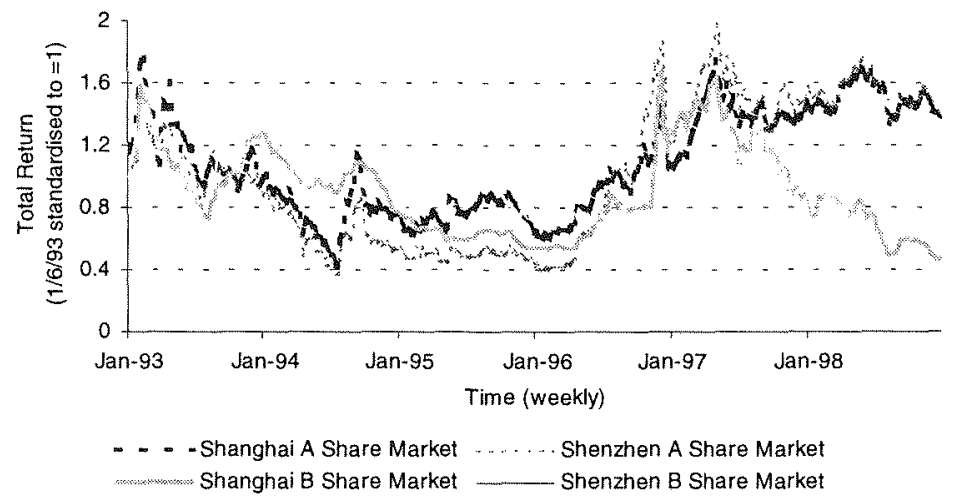

Source: DataStream.

better mobilise capital through a private market driven financial sector to fund the real sector. The state-owned sector will also increasingly rely on private capital markets to fund its recapitalisation efforts. The following are possible policy directions that could help achieve this goal. - Regularised and standardised government debt issuance. Forced debt issuance only perpetrates circular debt (or triangle debt) and marginalises the legitimacy of the government bond markets as real institutions for long-term fund raising. Developing a regular auction timetable, pre-announcing volumes, issuing standardised treasuries available to multiple classes of investor, and pricing these instruments via public bidding would allow China to develop a deep and liquid yield curve while minimising speculative behavior. This developed government bond market would give real prices to government debt serving as an important feedback mechanism for government policy, provide a real benchmark for pricing other fixed income instruments, allow for better risk management through standard risk management hedging techniques, help end the ongoing cycle of non-transparent circular debt finance between the government, state banks and the state-owned sector, and ultimately lower government debt financing costs by lowering market uncertainty. 


\section{Chapter 6}

- Increase stock and bond issuance to effect changes in corporate governance. While continued stock issuance and thus the transfer of ownership rights could dramatically change corporate governance in both state-owned and non state-owned companies, the state's dominance in both tradable and non-tradable shares has largely prevented the development of a new political economy in corporate ownership. On the one hand, ongoing issuance of cash dividends to state holders and share dividends or rights offerings to non-state equity holders as described by Xu and Wang (1997) has helped decrease the state's once unequivocal majority ownership stake in listed firms. On the other hand, even new stock issuance does not necessarily change corporate governance, as Xu and Wang (1997) found official managers and party officials hold key board and supervisory positions in many SOE incorporated firms. Therefore, the ongoing securitisation of firms, the issuance of shares to nonstate investors, and the de-emphasis of government appointed managers will increasingly empower shareholders to effectively pressure firms to maximise corporate profits.

However, the influence of non-state shareholders is also critical to maximising these positive changes. Importantly, Xu and Wang's (1997) empirical modelling found that in China large institutional holders exert profit-maximising behaviour on firms while individual investors have little effect on Chinese listed companies. From these conclusions, it will be critical for China to continue developing the mutual fund industry and to promote other forms of institutional stock and bond portfolio management. ${ }^{24}$

Finally, overall corporate bond issuance needs to catch up with total equity issuance to prevent an unbalanced capital market and provide firms with longer term debt finance options. Secondary markets need to be promoted in corporate bonds to allow the market to find real prices and limit the liquidity premium required by voluntary investors to hold such corporate securities. Furthermore, both issuance markets-but especially the corporate debt issuance market-need to be based more on objective financial criteria and be less politicised.

- Invest heavily in technical trading systems and vigilantly continue to upgrade financial reporting standards and legal rights of share and bond holders. Learning from the experience of countries like Japan, a lack of simulations payments, the lack of a corporate bond repo 
market, inefficient settlement systems, and the lack of unified real time price sources will dramatically hinder the development of both corporate and government securities markets. To date China has rapidly been upgrading its trading systems but additional investments are needed to keep pace with the increasing volume of total debt and equity issuance as well as to expand the scope of distribution. Without full financial disclosure, proper enforcement market regulations, and an extension of Article 214 to the bond and derivatives markets, the mechanism for shareholders to exert positive changes on corporate governance will be marginalised, poor firm investment decisions will go unchecked, and insider trading will dominate the exchanges. Finally, although hopefully assisted by the September 1998 formation of the China Chengxin Credit Rating Company-a joint venture including Fitich IBCA-accurate company risk ratings are still lacking.

- Actively open the domestic market to foreign banking and securities firms. Foreign firms will bring competitive bidding and risk valuations to the domestic market to determine real prices-real prices are a critical information component missing from the Chinese market at present and the longer prices remain distorted the greater the potential for asset bubbles. They will also facilitate financial services technology and skill transfer, and create future distribution links to foreign client markets for future placement of Chinese securities.

Fears that allowing domestic banks to compete directly in deposittaking activity will lead to the immediate collapse of Chinese firms should not materialise given empirical historical examples in Japan and Latin America. The development of an advanced domestic capital market necessary to finance future government spending and assist in the recapitalisation of the state sector will take considerably longer in isolation. 


\section{Notes}

1 Prior to the reforms of the late 1970 s and early 1980 s the cash plan was set independently of the credit plan, thus creating monetary segmentation. However, by the late 1980 s the cash plan was more indicative and of secondary importance.

${ }^{2}$ However, as reported by Wu (1995), until a profitable commercial based lending market was developed, it would remain in a bank manager's best interest to pay employees.

${ }^{3}$ Merrill Lynch (1998) lending estimates.

${ }^{4}$ In addition to the state-owned banks, the consolidated balance sheets for the national banking sector also includes the People's Bank of China, the Bank of Communications, CITIC Industrial Bank, and postal savings deposit institutions. However, this consolidated balance sheet provides the best available proxy for pure state banking behaviour.

${ }^{5}$ Other major PBC-forced closures include the closure of China Venturetech Investment Corp and Hainan Development Bank.

${ }^{6}$ The Industrial Bank of Japan, Dai Ichi Kangyo Bank, Citibank, Standard Charter Bank, the Hong Kong and Shanghai Banking Corp, Bankque Indosuez, Sanwa Bank, and Tokyo-Mitsubishi Bank.

7 For 1988 , inter-bank lending amounted to 345 per cent of total incremental bank lending for that year (Xia 1995).

${ }^{8}$ For example, Girardin (1997) founds that banks were dominant in Shanghai while financial institutions were dominate in Wuhan.

${ }^{9}$ See Girardin (1997) for full details of these new stipulations.

${ }^{10}$ Although consolidated inter-bank liabilities and assets should net to zero, Girardin (1997) has also found significant discrepancies in this market.

${ }^{11}$ Despite the lack of current inter-bank lending data for the entire interbank market, a net liability is clear since: RCC's and UCC's total inter-bank activity is on average less than 10 per cent of that for state bank activity; foreign banks have only recently begun to participate in the inter-bank market on a limited basis; TICs are net borrowers in this market; and total assets of the remaining categories are relatively insignificant. Clearly total assets and liabilities should net to zero if properly accounted for.

12 In 1997 the weighted average interest rates were 10.4 per cent, 11.13 per cent, 10.64 per cent, 11.09 per cent, 11 per cent, 11.01 per 
cent, and 10.6 per cent for overnight, 7 days, 20 days, 30 days, 60 days, 90 days, and 120 days respectively.

${ }^{13}$ As reported by the Economic Intelligence Unit (1998).

${ }^{14} 270$ billion yuan of special treasury bonds were issued to recapitalise state-owned commercial banks in September 1998, 100 billion yuan of special treasury bonds were placed with state banks to fund the central government's fiscal expansion, and in April 1998 the Ministry of Finance auctioned 45 billion yuan in $T$ bonds designated for the four sole state-owned banks. However the latter will be tradeable on the inter-bank bond market.

${ }^{15}$ Prior to this type of auction, the banks' sources of fund-of which 90 per cent came from bond issuance to commercial banks and savings deposit affiliates of the State Postal Bureau-were forced upon buyers through a mandatory quota system under government set interest rates. Equally importantly, greater freedom is being given to issuers to determine the terms of their debt issuance, coupon rate and maturity schedule.

${ }^{16}$ Figures taken from SAFE, Merrill Lynch (1998) and Reuters.

17 For example China was the first country to issue global bonds after the Russian debt crisis in summer 1998 with its US $\$ 1$ billion 10 year global bond that was sold at a yield to maturity of 7.346 per cent in autumn 1998.

${ }^{18}$ For example the US $\$ 100$ million global bond issued in October 1997 and maturing in 2006 was widely believed to be largely bought by major Chinese state-controlled banks. Marginal spreads between various duration assets also create suspicion of both illiquid assets and intervention.

${ }^{19}$ Figures taken from Financial Times, London, 30 December 1998 and State Information Council.

${ }^{20}$ The East Asian crisis decreased activity on the $\mathrm{H}$ share market; in 1998 there were only two new $\mathrm{H}$ shares (Huaneng Power and Yanzhou) and one Red Chip (Zhu Kuan development), down from 1997 where there were $16 \mathrm{H}$ share listings raising HK\$32.04 billion and ten red chips raising $\mathrm{HK} 39$ billion. And while the Red Chip and to a lesser extent the $\mathrm{H}$ share market will likely stagnate in 1999 due both to the effect of GITIC's collapse on investor confidence in China and overall stagnation of the Hong Kong and Chinese economies, a recovery of China's economy will likely bring about a heavy calendar of new issues in both these markets in the coming years. 
${ }^{21}$ Objective requirements are the following: a minimum capitalisation of over five million yuan; 25 per cent sale to the public; over 500 shareholders, with any shareholder holding over five per cent being registered and approved; and the company must have shown a profit for the last two years.

${ }^{22}$ The B share market's settlement period of $T+3$ is largely a function of exchange rate non-convertibility and an underdeveloped custodian system in this market.

${ }^{23}$ The lack of these two factors are just some of the major reasons behind the underdevelopment of similar markets in Japan.

${ }^{24}$ China only has closed-end mutual funds trading on the various exchanges. The Wuhan Securities Investment Fund was China's first, launched in 1991 and as of 1993 there were 73 listed mutual funds. However, since 1993 the PBC has increasingly regulated the issuance of new funds and only recently have officially registered funds begun to increase, although in 1995 there were 51 informally registered funds trading on China's various exchanges. The most recent new investment funds issued in 1998 were the Kaiyuan fund managed by the China Southern Securities company listed on the Shenzhen exchange, and the Jintai fund managed by Guotai Securities Company listed on the Shanghai exchange. 